\title{
Shipping container equipped with controlled atmosphere: Case study on table grape
}

\author{
Bernardo Pace, ${ }^{1}$ Maria Cefola, ${ }^{1}$ Antonio Francesco Logrieco, ${ }^{2}$ Berardo Sciscio, ${ }^{3}$ Antonio Sacchetti, ${ }^{3}$ \\ Massimiliano Siliberti, ${ }^{3}$ Paolo Laforgia, ${ }^{4}$ Angelo Amodio, ${ }^{4}$ Giovanni Calderoni, ${ }^{5}$ \\ Claudio Achille Garavelli, ${ }^{6}$ Maria Luisa Amodio, ${ }^{7}$ Giancarlo Colelli ${ }^{7}$
}

\begin{abstract}
${ }^{1}$ Institute of Science of Food Production, CNR-National Research Council of Italy, c/o CS-DAT Foggia; ${ }^{2}$ Institute of Sciences of Food Production, CNR-National Research Council of Italy, Bari; ${ }^{3}$ Tera Srl, Conversano (BA); ${ }^{4}$ IFAC spa, Acquaviva delle Fonti (BA); ${ }^{5}$ Ditro srl, Modugno (BA); ${ }^{6}$ Department of Mechanics, Mathematics, and Management, Politecnico di Bari; ${ }^{7}$ Department Science Agriculture, Food and Environment, University of Foggia, Italy
\end{abstract}

\begin{abstract}
A prototype of shipping container equipped with controlled atmosphere (CA) system (CA-prototype), was used for the simulation of the cold transport of table grapes (cv Italia). The CAprototype was realised by IFAC SPA, within the Research Project Continnova. It is equipped with a cooling system in order to work at a temperature between $-20^{\circ} \mathrm{C}$ and $+15^{\circ} \mathrm{C}$. The $\mathrm{CA}$ management is realised through the control system and the connections with the remote application. The experimental simulation of the cold transport was realised putting 20 boxes of table grapes inside the CA-prototype (set at $20 \% \mathrm{O}_{2}+10 \% \mathrm{CO}_{2}$ in nitrogen), other 20 in a refrigerated room using a $\mathrm{SO}_{2}$ pad inside each box, the remaining 20 in a cold room (Control) without $\mathrm{SO}_{2}$ pad for 12 days at $5^{\circ} \mathrm{C}$. At the end of the simulated transport, for each postharvest solution, 10 table grapes boxes were analysed,
\end{abstract}

\footnotetext{
Correspondence: Bernardo Pace, Institute of Sciences of Food Production (ISPA) National Research Council (CNR), via G. Amendola 122/O, 70126 Bari, Italy.

Tel.: +39.080.592.9304.

E-mail: bernardo.pace@ispa.cnr.it
}

Key words: Shipping containers; controlled atmosphere; fruits; transport; logistic chain.

Acknowledgements: the research leading to these results has received funding from Puglia region: Avviso Aiuti a Sostegno dei Cluster Tecnologici Regionali per l'Innovazione, Continnova Project: Container innovativo isotermico intermodale equipaggiato con atmosfera controllata per il trasporto di prodotti ortofrutticoli freschi (cod. VFQA3D0). The authors thank Giacomo Suglia President of APEO (Associazione Produttori Esportatori Ortofrutticoli) for the kind collaboration.

Received for publication: 15 March 2019.

Accepted for publication: 1 August 2019.

${ }^{C}$ Copyright: the Author(s), 2020

Licensee PAGEPress, Italy

Journal of Agricultural Engineering 2020; LI:954

doi:10.4081/jae.2020.954

This article is distributed under the terms of the Creative Commons Attribution Noncommercial License (by-nc 4.0) which permits any noncommercial use, distribution, and reproduction in any medium, provided the original author(s) and source are credited. while the remaining 10 were stored for 3 days at $20^{\circ} \mathrm{C}$ in air with the aim to simulate a shelf-life period. CA-prototype allows preserving table grapes visual quality, delaying browning and maintaining berry turgidity, extending the shelf-life until 12 days at $5^{\circ} \mathrm{C}$. Finally, CA-prototype resulted a valid alternative to the commonly used $\mathrm{SO}_{2}$ pads, which are under constant revision because of its potential allergenic effects.

\section{Introduction}

Fresh fruits and vegetables are perishable products and from the field to the table, during the postharvest supply chain, they might loss the organoleptic and nutritional characteristics that determine their quality to the consumer (Kader, 2002a). During the logistic chain, temperature management is the most effective tool for preserving the quality of fresh horticultural commodities (Kader, 2002a). Additional postharvest life may be achieved through modification of the atmosphere surrounding the product: modified (MA) and controlled atmospheres (CA) usually involve a reduction of $\mathrm{O}_{2}$ and/or an increase in $\mathrm{CO}_{2}$ levels and can result in many benefits. In fact, it has been reported that a proper modification of the atmosphere, in combination with the appropriate temperature, can reduce the commodity's respiration rate, mass loss and the sensitivity to ethylene. Moreover, MA or CA can delay ripening and softening, and could minimise the incidence of some physiological disorders and decay, thereby maintaining product freshness and quality longer than might otherwise be possible (Zagory and Kader, 1989; Kader, 2002b; Yahia, 2009; Amodio et al., 2018). The main difference between CA and MA storage is in the degree of control of the gaseous composition of the storage atmosphere. The CA implies a higher degree of control than MA in maintaining specific levels of $\mathrm{O}_{2}, \mathrm{CO}_{2}$, and other gases (Kader, 2002b). Currently CA is used for the storage of apples, kiwifruit, and pears and remain at experimental level on other horticultural commodities. The effectiveness of CA depends on cultivar, climacteric nature, storage temperature, selected concentration of gases, stage of maturity, commodity quality at harvest and pre-storage treatments. If the conditions are optimal for the chosen crop, senescence will be delayed by reducing respiration rate and substrate oxidation, delaying ripening of climacteric fruit and reducing the rate of ethylene production (Thomson, 2010). The effects of CA conditions on the physiology and quality of many table grape varieties have been evaluated (Crisosto et al., 2002; Artés-Hernandez et al., 2004). These Authors have shown that, in table grapes, the application of $\mathrm{CA}$ of high $\mathrm{CO}_{2}$ could retard senescence, reduce stem and berry respiration, limit rachis browning and decay and preserve berry firmness. In agreement, 
Cefola and Pace (2016) found good results in terms of preservation of sensory as well as nutritional quality using an atmosphere concentration $20 \% \mathrm{O}_{2}$ plus $10 \% \mathrm{CO}_{2}$ on organically-grown table grapes (cv. Italia).

Nowadays, CA technology is applied mainly for storage and less for transportation. Factors that limit its wider use are mainly due to the high costs associated with the preparation and management of the system, but also the lack of know-how and efficient technologies. Currently for the transport of fresh fruits and vegetable are used shipping containers, which are mainly based on the management of low temperature. Recently Maersk Container Industry (https://www.mcicontainers.com/products/star-cool/starcool-ca-plus) has developed a shipping container (Star Cool CA and $\mathrm{CA}^{+}$) equipped with a membrane system constructed of multilayered, high-tech polymer film, that allows the controlled removal of carbon dioxide while the auto-fresh air intake regulates oxygen level for the optimum atmosphere. The active CA technology proposed by Daikin's is based on a zeolite active atmosphere separation technology. It reduces the $\mathrm{O}_{2}$ concentration inside container using $\mathrm{N}_{2}$ from air.

Another available technology is Purfresh' CA technology, which works increasing $\mathrm{CO}_{2}$, decreasing $\mathrm{O}_{2}$, and adding ozone inside the refrigerated container environment. Starting from these considerations, the aim of this paper is: i) to describe a prototype of container equipped with CA system (CA-prototype); ii) to evaluate the performance of the CA-prototype during the simulated transport of table grape respect to the storage in cold room with or without $\mathrm{SO}_{2}$ pads.

\section{Materials and methods}

\section{Storage facilities and experiments}

Table grapes (Vitis vinifera L., cv Italia), 70 boxes of about 7 $\mathrm{kg}$ each one, were provided by a farm (Ermes snc, Noicattàro, Italy) at the maturity stage (total soluble solid content of $16^{\circ}$ Brix, according to OIV, 2008) (Figure 1). Ten boxes were used for analysis at harvest, while the remaining 60 boxes were divided in three lots, each one representative of one postharvest solution applicable during the transport. In detail, 20 boxes were put inside a CA-prototype (set at $20 \% \mathrm{O}_{2}+10 \% \mathrm{CO}_{2}$ in nitrogen, without $\mathrm{SO}_{2}$ pad), other 20 in a refrigerated room (EVERmed mod. LCRR $625 \mathrm{~S}$, forced-air refrigeration, $700 \mathrm{~L}$., $\mathrm{RH} 90 \%$ ) using a $\mathrm{SO}_{2}$ pad (IMAL
Ltda Los Canteros Santiago Chile) inside each box, the remaining 20 in a refrigerated room (EVERmed mod. LCRR $625 \mathrm{~S}$, forcedair refrigeration, 700 L., $\mathrm{RH} 90 \%$ ) without $\mathrm{SO}_{2}$ pad. The storage in presence of $\mathrm{SO}_{2}$ pads represents a common storage solution applied for table grapes (Melgarejo-Flores et al., 2013). All storage facilities were used to simulate a transport of 12 days at $5^{\circ} \mathrm{C}$. At the end of the simulated transport, for each postharvest solution, 10 table grapes boxes were analysed, while the remaining 10 were stored for 3 days at $20^{\circ} \mathrm{C}$ in air with the aim to simulate a period of shelf-life. Table grapes were analysed in 10 replicates, at harvest, after the transport and at the end of the shelf-life period for the main quality traits.

\section{Description of the controlled atmospheres-prototype}

The prototype was realised by IFAC spa, within the Regional Research Project Continnova (Figure 2A and B). It is composed by isothermal sandwich panels manufactured by a well-known wet on wet method. Each isothermal sandwich panel had a size of $2 \times 2 \times 2$ $\mathrm{m}$ (Figure 2C). A deep description of the materials used to assemble the prototype are reported in Table 1 .

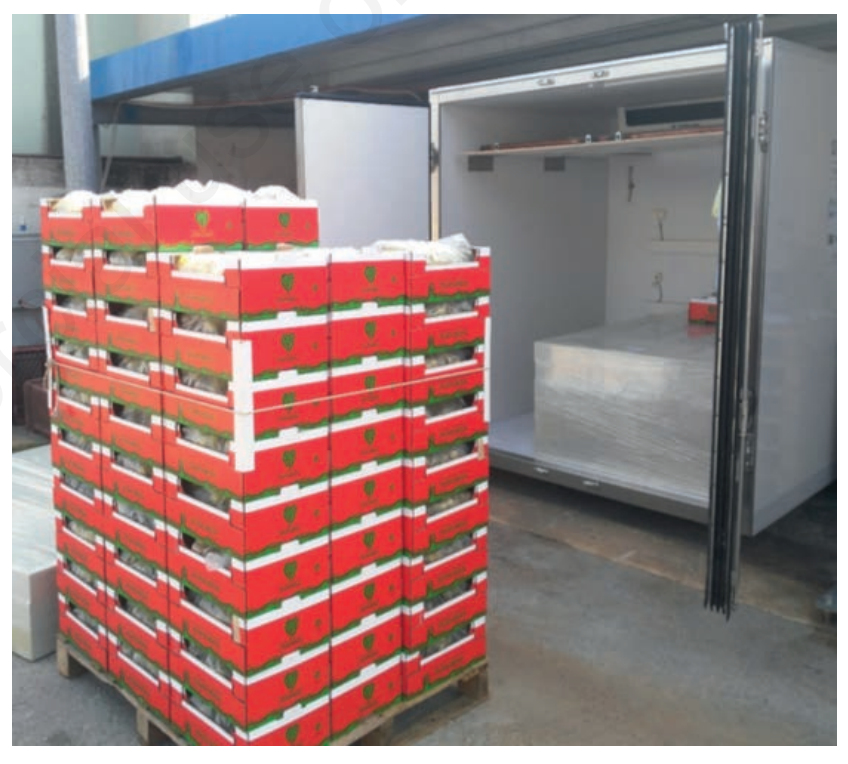

Figure 1. Table grape boxes used during the trial.

Table 1. Materials used to realise the isothermal sandwich panels of controlled atmosphere-prototype.

\begin{tabular}{|c|c|c|c|}
\hline Materials & Thickness & Mechanical characteristics & Thermal characteristics \\
\hline \multicolumn{4}{|l|}{ Polyurethane foams } \\
\hline $\begin{array}{l}\text { CORAFOAM-HPT } 40 \\
\text { Low density and very low } \\
\text { thermal conductivity }\end{array}$ & $\begin{array}{l}76 \mathrm{~mm} \\
\text { (density } 40 \mathrm{~kg} \mathrm{~m}^{-3} \text { ) }\end{array}$ & $\begin{array}{l}\text { Compressive strength } 350( \pm 50) \mathrm{kPa} \\
\text { Tensile strength } 580( \pm 60) \mathrm{kPa} \\
\text { Perpendicular strength } 260( \pm 40) \mathrm{kPa}\end{array}$ & Thermal conductivity $20 \mathrm{~mW} \mathrm{mk}^{-1}$ \\
\hline \multicolumn{4}{|l|}{ Glass fibre fabrics } \\
\hline $\begin{array}{l}\text { Complex ROV/R3D/WR/ROV } \\
\text { Polyester resins based on } \\
\text { dicyclopentadiene, having } \\
\text { styrene content lower than } \\
\text { conventional resins }\end{array}$ & $\begin{array}{l}3 \mathrm{~mm} \\
\text { (mass } 1.5 \mathrm{~kg} \mathrm{~m}^{-2} \text { ) } \\
\text { Distitron } 100 \mathrm{CS} \\
\text { DCPD - 28\% styrene }\end{array}$ & $\begin{array}{l}\text { High integrity- good processing - } \\
\text { good mechanical properties - } \\
\text { Excellent impregnations } \\
\text { Tensile strength } 75 \mathrm{MPa} \\
\text { Resistance to bending } 130 \mathrm{MPa} \\
\text { Tensile modulus } 3400 \mathrm{MPa}\end{array}$ & \\
\hline $\begin{array}{l}\text { Door dimensions } \\
\text { Door rubber in EPDM }\end{array}$ & $920 \times 1840 \mathrm{~mm}$ & Density $1.2 \mathrm{~g} \mathrm{~cm}^{-3}$ & $-35^{\circ} \mathrm{C}+125^{\circ} \mathrm{C}$ \\
\hline
\end{tabular}


The CA-prototype load is possible by two front doors assembled and equipped with triple level of rubber specific to limit the gas losses during the transport and to guarantee a hermetical closing. Moreover, it is equipped with a cooling system (Thermoking V300 20) in order to work at a temperature between $-20^{\circ} \mathrm{C}$ and $+15^{\circ} \mathrm{C}$. As for the CA management, the block diagram of the CA prototype with the control system and connections with the software to remote application for data and settings exchange is reported in Figure 3. In detail, the CA-prototype is equipped with the following components: i) $\mathrm{CO}_{2}$ and $\mathrm{N}_{2}$ gas cylinders, located below the CA-prototype; ii) $\mathrm{CO}_{2}$ preheating device, electrically powered from electronic control unit (ECU); iii) $\mathrm{CO}_{2}$ and $\mathrm{N}_{2}$ diffusers that allow controlled gas injection into CA-prototype; iv) controlled system for air introduction or extraction into or out from CA-prototype, atmosphere recirculation system, for homogenous gas mixing in the atmosphere; v) sensors set, respectively to monitoring pressure (P) (Jumo Midas 40.1001, 0-100 bar $\pm 0.5 \%$ ), temperature (T) and relative humidity (RH) (Aecl AHT303-Vax-A, RH 0-100\% $\pm 2 \%$; $\mathrm{T}-20^{\circ} \mathrm{C}-85^{\circ} \mathrm{C} \pm 0.3^{\circ} \mathrm{C}$ ) and concentrations of $\mathrm{CO}_{2}$ (NDIR sensor, $0-100 \% \pm 0.002 \%$ ) and $\mathrm{O}_{2}$ (Alfa sense, O2-A2, $0-20.9 \%$ $\pm 0.6 \%)$ into the CA-prototype. These sensors are connected to the ECU. The management of CA inside the CA-prototype is operated by hardware and software components below reported.
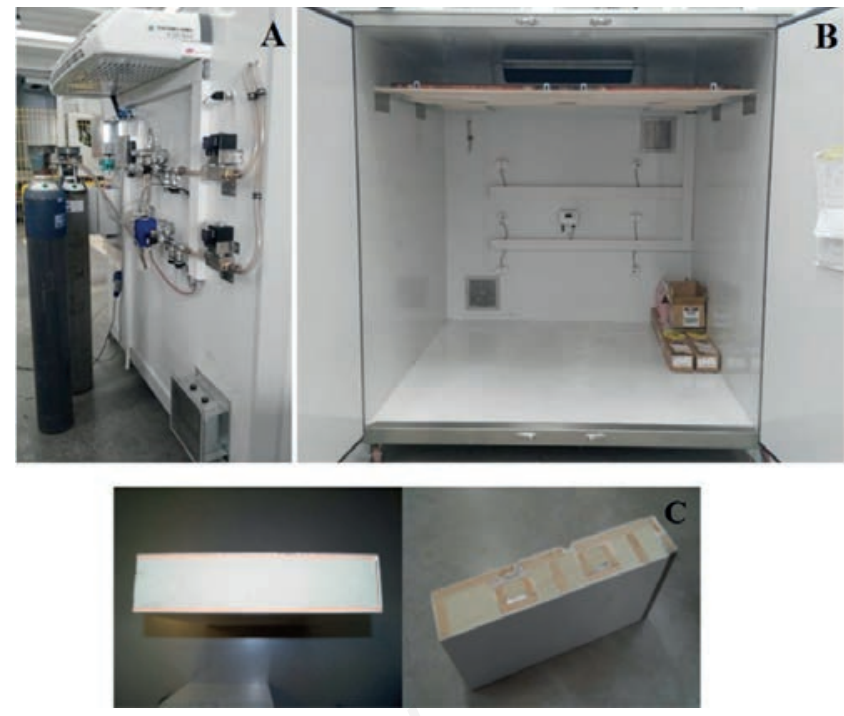

Figure 2. External (A) and internal (B) parts of the controlled atmosphere (CA)-prototype, isothermal sandwich panel used to build the CA-prototype (C).

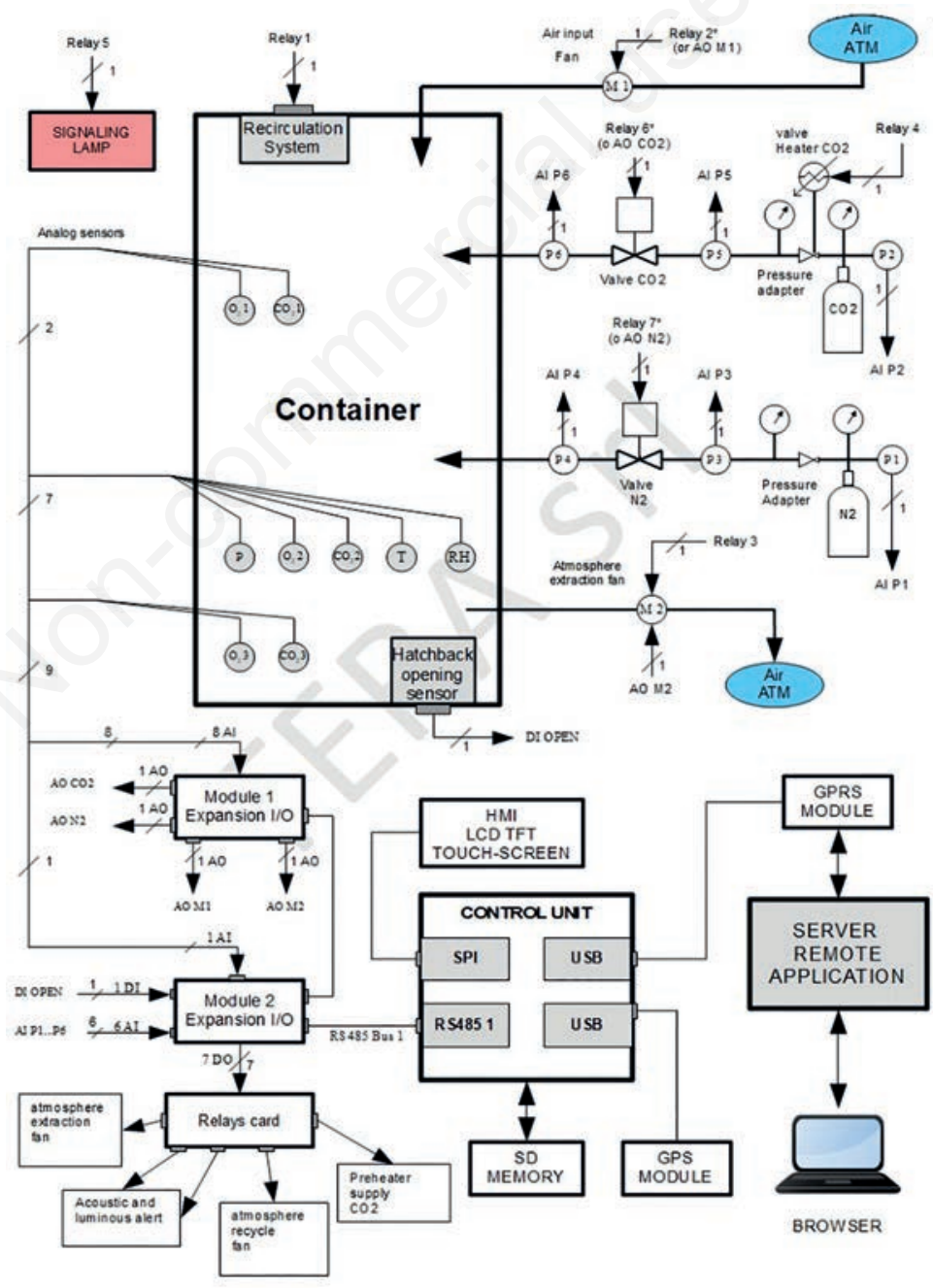

Figure 3. Block diagram of the controlled atmosphere prototype plant and control system and connection with the remote application. (Source not copyrighted: https://www.terasrl.it/pf/sistema-per-controllo-atmosfera/). 
Hardware components: i) ECU; ii) signal sensors and transducers; iii) input/output modules (Shj Electronic S5140 - S5134) connected to ECU; iv) geo-localisation device connected to ECU; v) GPRS/UMTS/HSDPA device for data transfer to ECU.

Software components: i) embedded Linux operative system; ii) software module to acquire and record data from input/output modules; iii) software application to set process values in CA-prototype; iv) software module to record process values in CA-prototype; v) software module to transfer data recorded from CA-prototype to the digital platform. Moreover, with the aim to describe the prototype operation modes, in Figure 4 a detailed flow chart is reported. To keep desired $\mathrm{O}_{2}$ and $\mathrm{CO}_{2}$ concentration values during

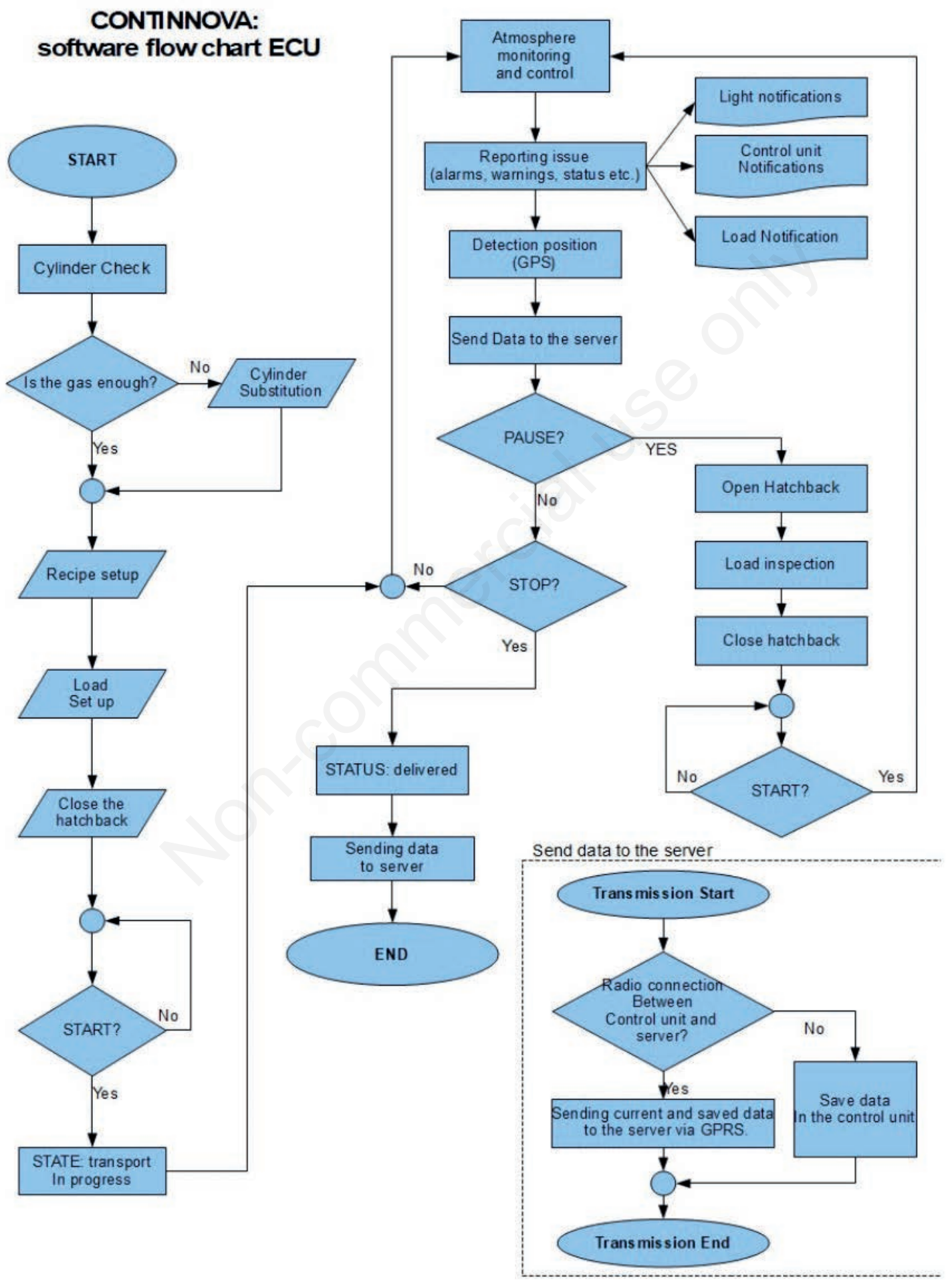

Figure 4. Flow chart of the prototype operation modes. 
transportation, process control system performs the following tasks: i) process control system cyclically measures the $\mathrm{CO}_{2}$ and $\mathrm{O}_{2}$ concentrations; ii) process control system compares measured values with $\mathrm{CO}_{2}$ and $\mathrm{O}_{2}$ settings; iii) process control system calculates control actions.

Regarding, the last point, ECU software compute control actions. $\mathrm{O}_{2}$ increments are obtained with air injection (opening shutters), while $\mathrm{O}_{2}$ reduction are obtained adding $\mathrm{N}_{2}$. On the other hand, $\mathrm{CO}_{2}$ increments are obtained with $\mathrm{CO}_{2}$ injection, despite its reduction is realised by air injection. The controller checks the $\mathrm{O}_{2}$ and $\mathrm{CO}_{2}$ concentration each hour, for $7 \mathrm{~min}$, and restores the setpoint values. This allows maintaining almost constant at the setpoint values the $\mathrm{O}_{2}$ and $\mathrm{CO}_{2}$ percentage.

\section{Quality analysis}

Visual quality (VQ), was evaluated using a hedonic scale from 5 to 1 ( 5 =excellent; $4=$ good; $3=$ fair, limit of sensory acceptability; $2=$ poor; 1 =very poor). Rachis browning ( $\mathrm{rB})$, was scored on a rating scale from 1 to 5 (1=absence, $2=$ light; $3=$ moderate; $4=$ severe; $5=$ extreme). For $\mathrm{rB}$ evaluation, panellists used the scale reported by Lichter et al. (2011) as reference.

Berry firmness was measured using a firmness tester (ZwickLine Z0.5; Zwick/Roell, Ulm, Germany) as the relative deformation of the berry fruits up to a $10 \mathrm{~N}$ load (deformation method), by using a plate of $100 \mathrm{~mm}$ of diameter, and was expressed in percentage respect to berry diameter (Cefola et al., 2011). Samples were weighed individually and mass loss was expressed as g per $100 \mathrm{~g}$ of fresh mass .

Colour parameters $\left(L^{*}, a^{*}\right.$ and $\left.b^{*}\right)$ were measured, for each replicate, on 3 random points on peel surface of 10 berries using a colorimeter (CR-400, Konica Minolta, Osaka, Japan) in the reflectance mode and in the CIE $L^{*} a^{*} b^{*}$ colour scale. The colorimeter was calibrated with a standard reference having values of
$L^{*}, a^{*}$ and $b^{*}$ corresponding to $97.55,1.32$ and 1.41 , respectively. In order to measure colour variations respect to fresh berries, at each sampling day $\Delta \mathrm{E}$ was calculated using the following formula: $\Delta \mathrm{E}=\left[\left(\mathrm{L}_{0}{ }^{*}-\mathrm{L}^{*}\right)^{2}+\left(\mathrm{a}_{0}{ }^{*}-\mathrm{a}^{*}\right)^{2}+\left(\mathrm{b}_{0}{ }^{*}-\mathrm{b}^{*}\right)^{2}\right]^{1 / 2}$ (Martínez-Sanchez et al., 2011). The relative water content (RWC) of rachis was measured initially and during storage on rachis pieces of about one centimetre each one for a total of $4( \pm 0.3) \mathrm{g}$ of rachis for each replicate (Rosales et al., 2013). The pieces were obtained cutting the rachis with a knife cutter. They were weighed fresh (Fw), after 24 $\mathrm{h}$ rehydration $(\mathrm{Rw})$ in distilled water at ambient temperature and after drying (Dw) at $65^{\circ} \mathrm{C}$ in oven until constant mass. The RWC was calculated as percentage, using the following formula (Sanchez-Ballesta et al., 2006): RWC $(\%)=(\mathrm{Fw}-\mathrm{Dw}) /(\mathrm{Rw}-$ Dw) $\times 100$.

\section{Statistical analysis}

Data related to table grape were subjected to one-way ANOVA to evaluate significant difference $(\mathrm{P} \leq 0.05)$ between the two-storage condition $\left(12\right.$ days at $5^{\circ} \mathrm{C}$ or 3 days at $20^{\circ} \mathrm{C}$ ) and among fresh samples and that one stored in each postharvest solution (CA-prototype or $\mathrm{SO}_{2}$ pad or cold room) after the simulated transport (12 days at $5^{\circ} \mathrm{C}$ ) and shelf-life $\left(3\right.$ days at $\left.20^{\circ} \mathrm{C}\right)$. Mean were separated applying the least significant difference test.

\section{Results and discussion}

Changes in $\mathrm{O}_{2}, \mathrm{CO}_{2}$, and temperature inside CA-prototype during the experiment are reported in Figure 5. It is possible to note as the CA-prototype is able to correct the gas composition maintaining the atmosphere composition at the set-up level. The effectiveness of CA for reefer containers is dependent the maintenance of the temperature and on commodity respiration rate and
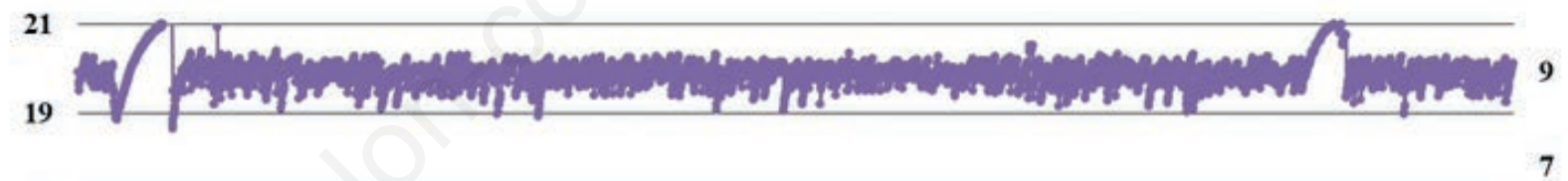

17
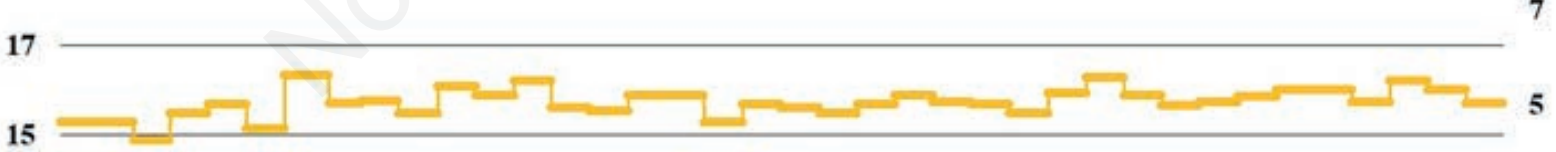

\section{ஓ 13}
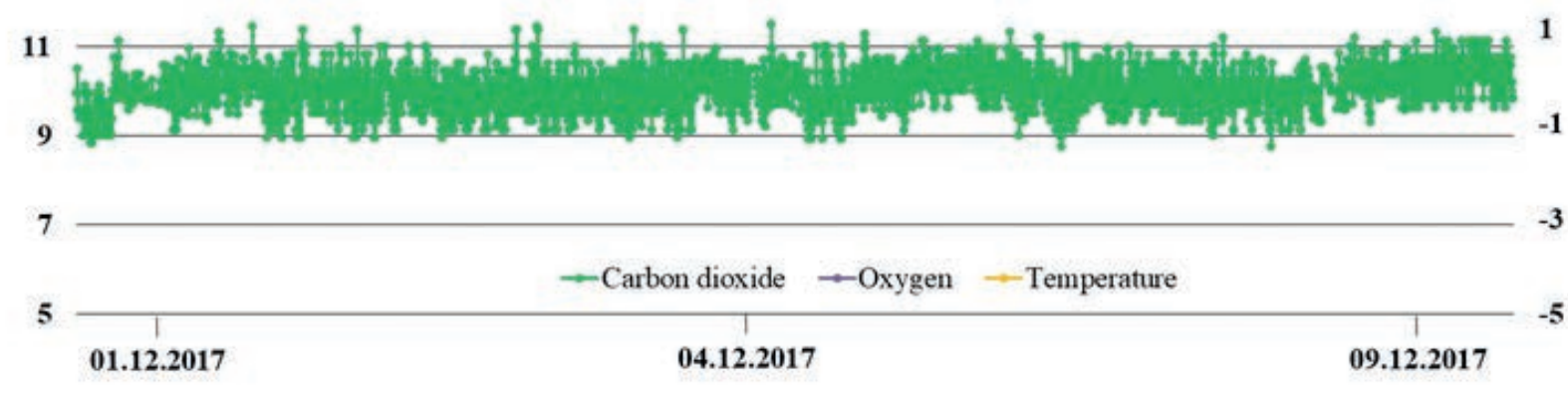

Figure 5. Example of the output elaborated by the software $\left[\mathrm{O}_{2}, \mathrm{CO}_{2}(\%)\right.$ and temperature $\left.\left({ }^{\circ} \mathrm{C}\right)\right]$ during the controlled atmosphere trial setup, recorded inside controlled atmosphere-prototype. 
maturity level (Bessemans et al., 2016). Potential air leakage in a reefer especially through the doors and fitting plastics curtains inside the doors, can reduce the degree of control over the gases in CA containers (Thompson, 2010).

Table grapes showed a good visual quality after the simulated transport in the CA-prototype and after the relative period of shelflife; similar results were obtained by table grapes stored in the presence of $\mathrm{SO}_{2}$ pads (Figure 6 and $7 \mathrm{~A}$ ). Considering the score 3 as the marketability limit, it is possible to transport table grapes in the CA-prototype for 12 days, with a consequent shelf-life of 3 days at $20^{\circ} \mathrm{C}$. Despite, table grapes samples cold stored (control) were scored at the marketability limit just at the end of the period of transport. Whereas, by using the $\mathrm{SO}_{2}$ pads the marketability is lost at the end of the shelf-life period (Figure 7A). These results on visual quality are in agreement with that one related to browning. Rachis browning was delayed by transport with CA-prototype, with positive effect also during the shelf-life (Figure 7B). As for the berry deformation and colour variation respect to fresh sample $(\Delta \mathrm{E})$, table grapes transported in the CA-prototype showed performance similar to $\mathrm{SO}_{2}$ pads; whereas a loss of turgidity and a browning was measured in table grapes stored only with the use of low temperature (Figure 7C and D). No significant differences among samples transported with the different system were detected for RWC (data not shown) and mass loss. The CA-prototype allows to preserve table grapes quality and to extend the shelf-life for the effect of atmosphere composition set $\left(20 \% \mathrm{O}_{2}+10 \% \mathrm{CO}_{2}\right.$ in nitrogen) on the respiration rate delay as previously reported (Cefola and Pace, 2016; Cefola et al., 2018). Moreover, it resulted a valid alternative to the common use of $\mathrm{SO}_{2}$ pads, which is under constant revision because of its potential allergenic effects (Balic et al., 2012; Cefola et al., 2015).

\section{Conclusions}

Results demonstrated that it is possible to transport table grapes in CA-prototype for 12 days $\left(20 \% \mathrm{O}_{2}+10 \% \mathrm{CO}_{2}\right.$ in nitrogen), time enough to reach new market. Moreover, after the transport period, table grapes can be marketable for 3 days at $20^{\circ} \mathrm{C}$, with a positive effect of $\mathrm{CO}_{2}$ residual on the overall quality. Moreover, the CA-prototype presents a high flexibility for the possibility to set all needed combination of atmosphere composition $\left(\mathrm{O}_{2}, \mathrm{CO}_{2}, \mathrm{~N}_{2}\right)$ and temperature (from -20 to $15^{\circ} \mathrm{C}$ ). The proposed system might be used to transport also other commodities, by setting the suitable atmosphere composition. Finally, the flexibility of the CA-prototype regards the possibility to use it as ripening chamber during transport, by improving it with ethylene sensors and gas cylinders.

Future researches are aimed to apply this system to other perishable commodities.

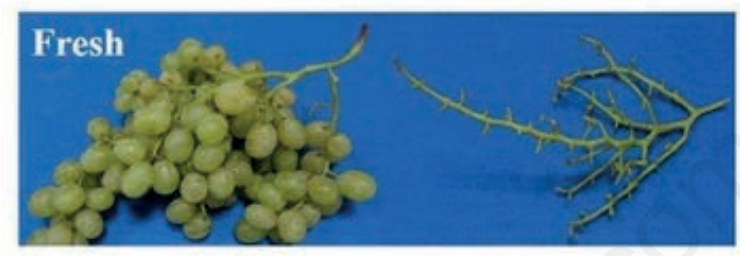

12 days at $5{ }^{\circ} \mathrm{C}$

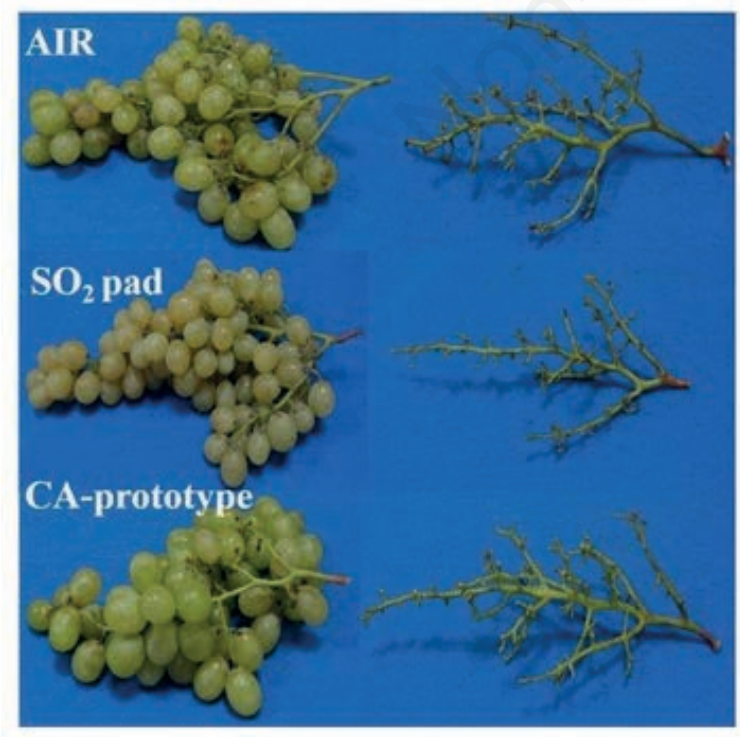

AIR

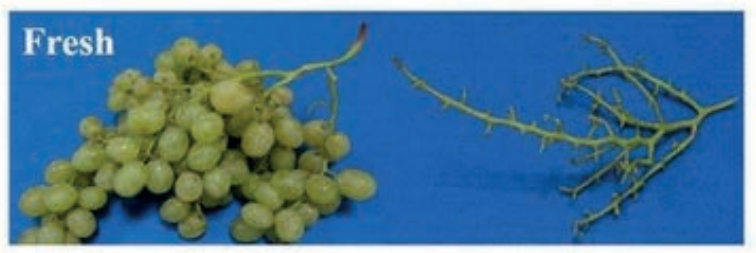

12 days at $5{ }^{\circ} \mathrm{C}+3$ days at $20^{\circ} \mathrm{C}$

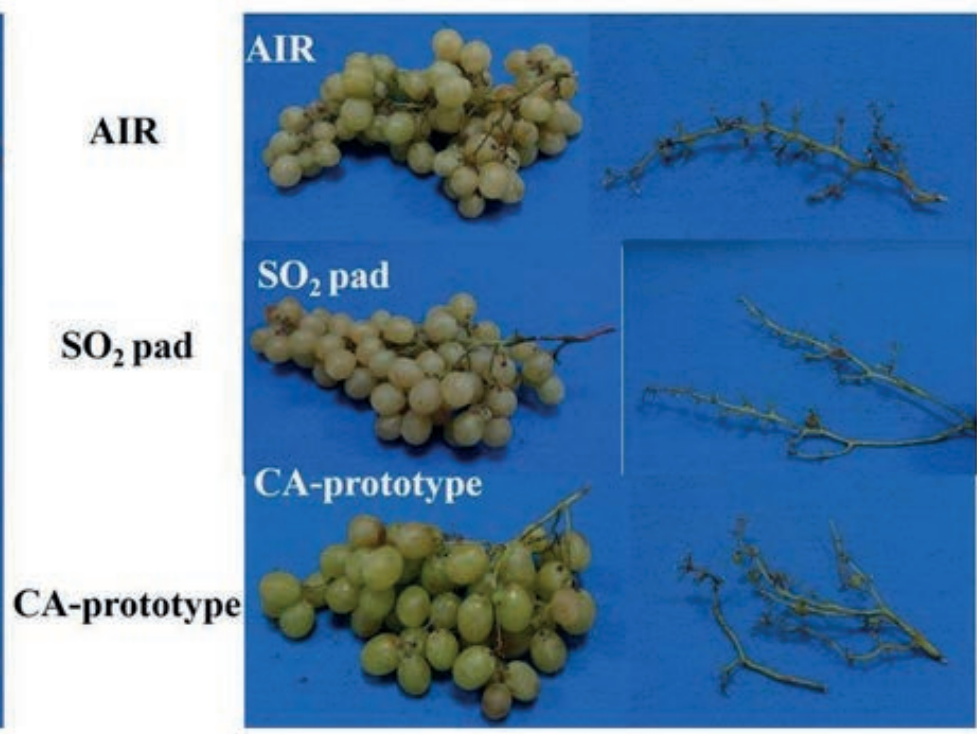

Figure 6. Appearance of table grape after the simulated transport of 12 days at $5^{\circ} \mathrm{C}$ and after an additional 3 days of shelf-life at $20^{\circ} \mathrm{C}$, in controlled atmosphere (CA)-prototype, cold room with $\mathrm{SO}_{2}$ pad or without (AIR) respect to fresh bunches. 

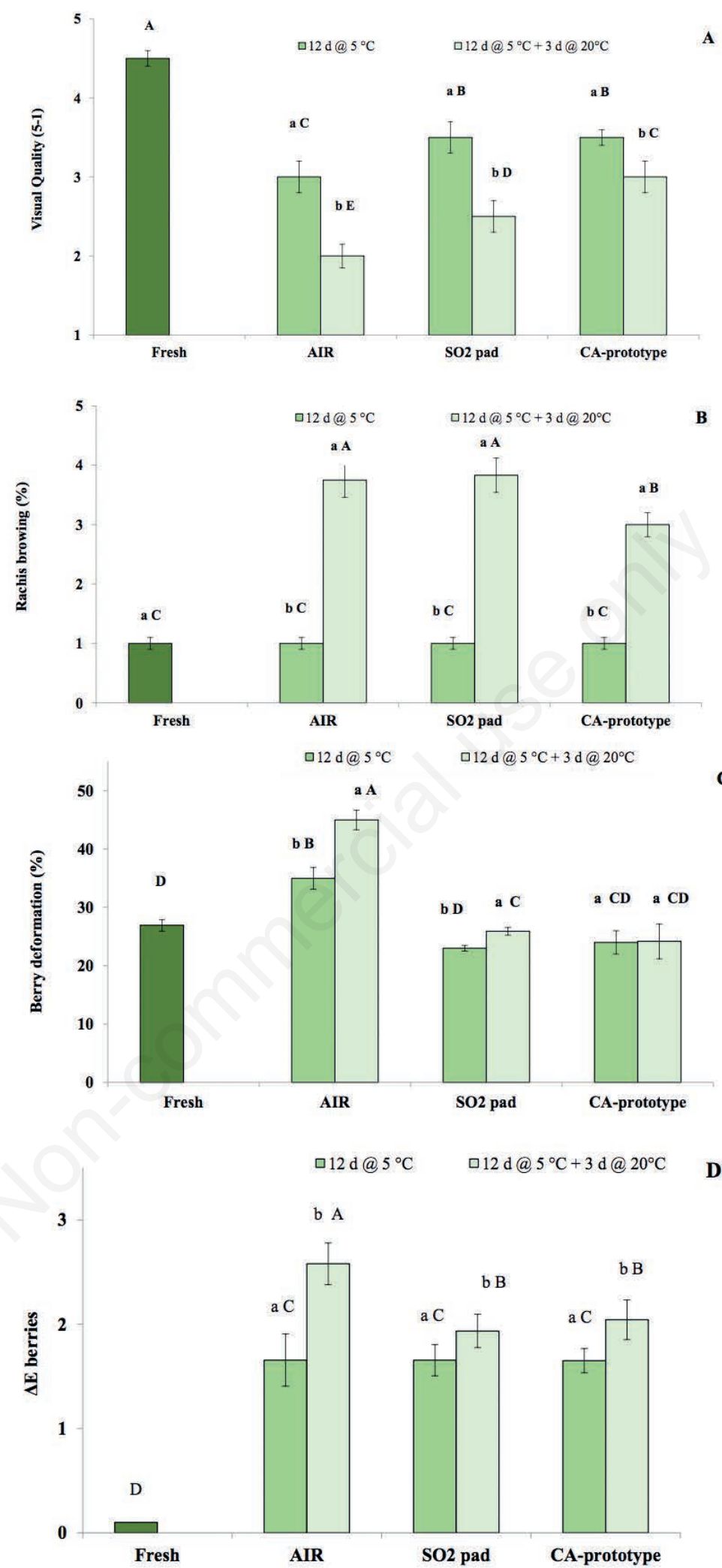

Figure 7. Changes in visual quality (A), rachis browning (B), berry deformation $(C)$ and berry colour variation, $\Delta E(D)$ after the simulated transport of 12 days at $5^{\circ} \mathrm{C}$ and after an additional 3 days of shelf-life at $20^{\circ} \mathrm{C}$, of table grape (cv Italia) in controlled atmosphere (CA)prototype, cold room with $\mathrm{SO}_{2}$ pad or without (AIR) respect to fresh bunches. Uppercase letters show significant difference among fresh and stored table grapes in the different postharvest solution after the simulated transport and shelf-life; lowercase letters indicate significant differences among stored table grapes in the different postharvest solution after the simulated transport and shelf-life. 


\section{References}

Amodio M.L., Colelli G., Cantwell M.I. 2018. Ammonia accumulation in plant tissues: a potentially useful indicator of postharvest physiological stress. Acta Hortic. 1194:1511-8.

Artés-Hernández F., Artés-Hernández E., Aguayo F. 2004. Alternative atmosphere treatments for keeping quality of 'Autumn seedless' table grapes during long-term cold storage. Postharvest Biol. Technol. 31:59-67.

Balic I., Moreno A., Sanhueza D., Huerta C., Orellana A., Defilippi B.G., Campos-Vargas R. 2012. Molecular and physiological study of postharvest rachis browning of table grape cv. Red Globe. Postharvest Biol. Technol. 72:47-56.

Bessemans N., Verboven P., Verlinden B.E., Nicolaï B.M. 2016. A novel type of dynamic controlled atmosphere storage based on the respiratory quotient (RQ-DCA). Postharvest Biol. Technol. 115:91-102.

Cefola M., Damascelli A., Lippolis V., Cervellieri S., Linsalata V., Logrieco A.F., Pace B. 2018. Relationships among volatile metabolites, quality and sensory parameters of 'Italia' table grapes assessed during cold storage in low or high $\mathrm{CO} 2$ modified atmospheres. Postharvest Biol. Technol. 142:124-34.

Cefola M., Pace B. 2016. High $\mathrm{CO}_{2}$-modified atmosphere to preserve sensory and nutritional quality of organic table grape (cv. 'Italia') during storage and shelf-life. Eur. J. Hortic. Sci. 81:197-203.

Cefola M., Pace B., Bugatti V., Vittoria V. 2015. Active coatings for food packaging: a new strategy for table grape storage. Acta Hortic. 1071;121-7.

Cefola M., Pace B., Buttaro D., Santamaria P., Serio F. 2011. Postharvest evaluation of soilless grown table grape during storage in modified atmosphere. J. Sci. Food Agr. 91:2153-9.

Crisosto C.H., Garner D., Crisosto G. 2002. High carbon dioxide atmospheres affect stored 'Thompson seedless' table grapes. HortSci. 37;1074-8.

Kader A.A. 2002a. Postharvest biology and technology: an overview. In: Kader A.A. (Ed)., Postharvest technology of horticultural crops. 3rd ed. University of California, Agriculture and Natural Resources, Pub. 3311. Oakland, CA, USA, pp 39-47.
Kader A.A. 2002b. Modified atmospheres during transport and storage. In: Kader A.A. (Ed)., Postharvest technology of horticultural crops. 3rd ed. University of California, Agriculture and Natural Resources, Pub. 3311. Oakland, CA, USA, pp 135-144.

Lichter A., Kaplunov T., Zutahy Y., Daus A., Alchanatis V., Ostrovsky V., Lurie S. 2011. Physical and visual properties of grape rachis as affected by water vapor pressure deficit. Postharvest Biol. Tech. 59:25-33.

Martínez-Sanchez A., Tudela J.A., Luna C., Allende A., Gil M.I. 2011. Low oxygen levels and light exposure affect quality of fresh-cut Romaine lettuce. Postharvest Biol. Tech. 59:34-42.

Melgarejo-Flores B.G., Ortega-Ramírez L.A., Silva-Espinoza B.A., González-Aguilar G.A., Miranda M.R.A., Ayala-Zavala J.F. 2013. Antifungal protection and antioxidant enhancement of table grapes treated with emulsions, vapors, and coatings of cinnamon leaf oil. Postharvest Biol. Technol. 86:321-8.

Rosales R., Fernandez-Caballero C., Romero I., Escribano M.I., Merodio C., Sanchez-Ballesta M.T. 2013. Molecular analysis of the improvement in rachis quality by high $\mathrm{CO}_{2}$ levels in table grapes stored at low temperature. Postharvest Biol. Technol. 77:50-8.

Sanchez-Ballesta M.T., Jiménez J. B., Romero I., Orea J.M., Maldonado R., Ureña Á.G.,Escribano M.I., Merodio C. 2006. Effect of high $\mathrm{CO} 2$ pretreatment on quality, fungal decay and molecular regulation of stilbene phytoalexin biosynthesis in stored table grapes. Postharvest Biol. Techno. 42:209-16.

Thompson A.K. 2010. Modified atmosphere packaging. In: Thompson A.K. (Ed.), Controlled atmosphere storage of fruits and vegetables. 2nd ed. CABI, Wallingford, UK, pp 81-115.

Yahia E.M. 2009. Introduction. In: Elhadi M.Y. (Ed.), Modified and controlled atmosphere for the storage, transportation, and packaging of horticultural commodities. CRC Press, Boca Raton, FL, USA, pp 1-3.

Zagory D., Kader A.A. 1989. Quality maintenance in fresh fruits and vegetables by controlled atmosphere. In: J.J. Jen (Ed.), Quality factors of fruits and vegetables-chemistry and technology. American Chemical Society, Washington, DC, USA, pp 174-188. 